\title{
FINDING A WAY: WOMEN'S STORIES OF DAILY SURVIVAL AFTER THE 1965 KILLINGS IN INDONESIA
}

\author{
Annie Pohlman
}

\section{Introduction: the 1965-1966 massacres in Indonesia}

In this essay I explore the experiences of women who lived through the mass killings of 1965-1966 and the strategies they developed to survive in the aftermath of that violence. Mass violence swept across Indonesia in the months and years following a military coup in Jakarta on 1 October 1965, and it had a profound impact on the lives of millions. In its wake, the Indonesian Army carried out a propaganda campaign to incite violence against its main political rival, the Indonesian Communist Party (Partai Komunis Indonesia or the PKI) and its supporters. With the willing participation of numerous civilian militia groups, the Army orchestrated the eradication of the Left in Indonesia. Approximately half a million people were killed and a further 1 million were rounded up during anti-Communist purges and held in political detention. Many died during torture or from hunger, disease, forced labour or a lack of medical care. ${ }^{1} \mathrm{Al}-$ though political groups are excluded from the 1948 United Nations Convention on the Prevention and Punishment of the Crime of Genocide, the 1965-1966 mass killings were genocidal in intent. ${ }^{2}$ As several scholars argue, these killings were intended to wipe out the political Left from the Indonesian polity. ${ }^{3}$ The leading scholar on the Indonesian case notes that the violence of 1965-1966 was "a successful exercise in national obliteration."

1 Robert Cribb, “Genocide in Indonesia, 1965-1966,” Journal of Genocide Research 3, no. 2 (2001), 219-39; Douglas Kammen and Katharine McGregor, eds., The Contours of Mass Violence in Indonesia, 1965-68 (Singapore: NUS Press and NIAS Press, 2012).

2 See Beth van Schaack, "The Crime of Political Genocide: Repairing the Genocide Convention's Blind Spot," Yale Law Journal 106, no. 7 (1997), 2259-91; Anton Weiss-Wendt, "Hostage to Politics: Raphael Lemkin on 'Soviet Genocide,' ” Journal of Genocide Research 7, no. 4 (2005), 551-59.

3 See Cribb, “Genocide in Indonesia,” 219-25; Helen Fein, "Revolutionary and Antirevolutionary Genocides: A Comparison of State Murders in Democratic Kampuchea, 1965 to 1979, and in Indonesia, 1965 to 1966," Comparative Studies in Society and History 35, no. 4 (1993), 796-823; Jess Melvin, "Mechanics of Mass Murder: How the Indonesian Military Initiated and Implemented the Indonesian Genocide” (PhD thesis, University of Melbourne, 2014); Annie Pohlman, "Incitement to Genocide against a Political Group: The Anti-Communist Killings in Indonesia,” Portal: Journal of Multidisciplinary Studies 11, no. 1 (2014), 1-22.

4 Cribb, “Genocide in Indonesia,” 237. 
During this period of mass killings and arrests - that continued apace until March 1966 - the Indonesian Army under Major General Suharto took government. What followed was three decades of authoritarian, military-backed rule, under a regime that named itself the "New Order" (1966-1998). Throughout this military regime, those with any connection to the former PKI experienced a range of repressive measures, and these were carried out not only against former members of the PKI but also former members of any of the organisations associated with the party, such as the women's organisation Gerwani (Gerakan Wanita Indonesia, the Indonesian Women's Movement), the trade union federation, SOBSI (Sentral Organisasi Buruh Seluruh Indonesia), and the farmers' and peasants' association, the BTI (Barisan Tani Indonesia). Measures were also taken against anyone imprisoned during the arrests that followed the coup, regardless of whether they had connections to the PKI. ${ }^{5}$ Prior to 1965, Communist supporters made up nearly one-quarter of Indonesia's then estimated 100 million population. ${ }^{6}$ Under the new military rule, Leftist associations were banned and therefore affiliation with such organisations was denied by many for fear of persecution. Anti-communism was a core pillar of the New Order, which maintained a vigilant and militant stance against Leftist politics over its 33-year rule. ${ }^{7}$

Repression against former prisoners and associates of the PKI took many forms. Particularly for those politically detained following the coup-some of whom remained incarcerated for a decade or more- the New Order government imposed a range of restrictions designed to impede their reintegration into society. ${ }^{8}$ Those known as ex-tapol (an abbreviation of "tahanan politik" or "political prisoner") were targeted upon release from prison with restraints on employment, movement, speech, residence and political participation. Furthermore, the family members of ex-tapol and those killed during the massacres, faced similar restrictions, all of which the New Order implemented without legal process and in the name of social inoculation against the alleged danger of a communist revival. ${ }^{9}$ By the 1980s, these restrictions had developed

\footnotetext{
5 Amnesty International, Indonesia: An Amnesty International Report (London: Amnesty International, 1977); Greg Fealy, The Release of Indonesia’s Political Prisoners: Domestic Versus Foreign Policy, 1975-1979 (Clayton, Victoria: Centre for Southeast Asian Studies, Monash University, 1995).

6 Rex Mortimer, Indonesian Communism Under Sukarno: Ideology and Politics, 1959-1965 (Ithaca: Cornell University Press, 1974), 366.

7 Robert Goodfellow, Api dalam Sekam: The New Order and the Ideology of Anti-Communism (Clayton, Victoria: Monash Asia Institute, 1995); Ariel Heryanto, State Terrorism and Political Identity in Indonesia: Fatally Belonging (London: Routledge, 2006); Katharine E. McGregor, History in Uniform: Military Ideology and the Construction of Indonesia's Past (Honolulu: University of Hawai'i Press, 2007).

8 Asia Watch, Human Rights in Indonesia and East Timor (New York: Human Rights Watch, 1988), 5-6.

9 Asia Watch, Human Rights, 6; Julie Southwood and Patrick Flanagan, Indonesia: Law, Propaganda, and Terror (London: Zed Press, 1983), 75-80.
} 
into the more formal "clean self” and "clean environment" restrictions — to be "clean” meant that one had no familial or other ties with persons killed or arrested following the coup. Those found to be "unclean" were barred from various forms of employment, citizenship, expression and movement. ${ }^{10}$

Aside from these formal restrictions, those seen to have former Leftist connections also experienced a range of social stigmas and economic difficulties. People identified as ex-tapol, and their families by association, were targeted by military and government officials through various forms of heightened surveillance. ${ }^{11}$ Former political prisoners had their identity cards stamped with the initials "E/T" (ex-tapol), becoming easily identifiable to officials. ${ }^{12}$ Forms of monitoring and restriction of movement were further reinforced by social surveillance by distrustful neighbours and community members; many former prisoners have spoken of how neighbours conducted monitoring on "unclean" former Communists in their midst. ${ }^{13}$ Barred from a wide range of educational and employment opportunities, many former prisoners, their children, grandchildren and other family members suffered significant financial difficulties.

While the worst of these repressive measures were lifted following the end of the New Order regime in 1998, the stigma of association with former Communists and political prisoners remains to this day. ${ }^{14}$ To date, the Indonesian government has delayed or blocked attempts to investigate or redress the violence of 1965; there has been no official apology or reparations made to survivors or victims' families. ${ }^{15}$ Given the impunity for historical cases of gross human rights violations in Indonesia, survivors and their advocates speak out about their experiences at some risk; those who choose to take part in truth-telling about past abuses do so under threat of reprisal from security services and hard-line groups within their communities. ${ }^{16}$

10 See Justus van der Kroef, “Indonesia’s Political Prisoners,” Pacific Affairs 49, no. 1 (1976), 34-60; Annie Pohlman, “A Fragment of a Story: Gerwani and Tapol Experiences,” Intersections: Gender, History and Culture in the Asian Context 10 (2004), http://intersections.anu.edu.au/issue10/pohlman.html.

11 See Asia Watch, Human Rights, 65-73; Fealy, The Release.

12 Tapol, “All Forms of Discrimination Must End,” Tapol Bulletin 130 (1995), 5-7.

13 Carmel Budiardjo, Surviving Indonesia's Gulag: A Western Woman Tells Her Story (London: Cassell, 1996), 103-10; Tapol, “All Forms of Discrimination,” 5-7.

14 Steven Miller, "Zombie Anti-Communism? Democratisation and the Demons of Suharto Era Politics in Contemporary Indonesia,” in After 1965: Causes, Responses and Memories of the Indonesian Genocide, eds. Katharine McGregor, Annie Pohlman and Jess Melvin (New York: Palgrave MacMillan, forthcoming).

15 International Centre for Transitional Justice (ICTJ) and the Commission for Disappeared Persons and Victims of Violence (KontraS), Derailed: Transitional Justice in Indonesia Since the Fall of Soeharto (Jakarta: ICTJ \& KontraS, 2011); Kimura Ehito, "The Struggle for Justice and Reconciliation in Post-Suharto Indonesia," Southeast Asian Studies 4, no. 1 (2015), 73-93.

16 Sri Lestari Wahyuningroem, "Seducing for Truth and Justice: Civil Society Initiatives for the 1965 Mass Violence in Indonesia,” Journal of Current Southeast Asian Affairs 32, no. 3 (2013), 115-42; Annie Pohlman, 
Since the end of the New Order, however, many survivors have indeed chosen to speak about their experiences. Survivors' testimonies have revealed how those killed and imprisoned during the mass violence of 1965-1966 experienced egregious violence, many suffering inhumane and dehumanising treatment. ${ }^{17}$ Those left behind when loved ones were rounded up also experienced violence and severe forms of hardship. Yet such stories are rarely examined in detail and are often treated as peripheral to narratives about those who experienced violence first-hand. ${ }^{18}$

In this essay, I examine the stories of two women who lost husbands, Ibu Arum and Ibu Moeliek, ${ }^{19}$ and the impact this had upon them and their families. I explore the suffering and resilience of these women and pay particular attention to their experiences in terms of financial hardship and the strategies they developed and deployed to survive. I also highlight the experiences of women in finding ways to persevere in the wake of genocidal violence, ensuring the survival of their children and other family members in the face of extreme violence, marginalisation and poverty.

\section{Women speaking of survival after the violence}

The topic of survival underpins many of the testimonies of women survivors, the term having multiple meanings for individual women. In some women's testimonies, survival meant immediate safety from direct threats of attack and imminent danger. When describing the weeks and months after the 1965 coup, women talked about having to hide or flee when soldiers and mobs of youth militias came to their homes in the night, sometimes taking members of their family or attacking entire households, looting and killing, even setting fire to the house. These stories convey the nightmare and panic of having to grab

\footnotetext{
“A Year of Truth and the Possibilities for Reconciliation in Indonesia," Genocide Studies and Prevention: An International Journal 10, no. 1 (2016), 60-78.

17 Southwood and Flanagan, Indonesia, 112-18; Kammen and McGregor, The Contours.

18 For exceptions, see Anton Lucas, trans., “Survival: Bu Yeti’s Story,” in The Indonesian Killings 1965-1966: Studies from Java and Bali, ed. Robert Cribb (Clayton, Victoria: Centre of Southeast Asian Studies, Monash University, 1990), 227-39; Yayan Wiludiharto, "Penantian Panjang di Jalan Penuh Batas: Kisah Keluarga Korban,” in Tahun yang tak Pernah Berakhir: Memahami Pengalaman Korban 65, Esai-esai Sejarah Lisan, eds. John Roosa, Ayu Ratih and Hilmar Farid (Jakarta: ELSAM, TRuK and ISSI, 2004), 61-85; Komnas Perempuan, Gender-Based Crimes Against Humanity: Listening to the Voices of Women Survivors of 1965 (Jakarta: Komnas Perempuan, 2007); Budiawan, "Living with the Spectre of the Past: Traumatic Experiences among Wives of Former Political Prisoners of the '1965 Event' in Indonesia," in Contestations of Memory in Southeast Asia, eds. Roxana Waterson and Kwok Kian-Woon (Singapore: NUS Press, 2012), $270-91$.

19 "Ibu" is a term that means both "wife" and "mother." All names given in this essay are pseudonyms, except when initials are employed in the source document. For example, see Komnas Perempuan, Gender-Based Crimes, 128.
} 
children and meagre possessions and flee, uncertain whether they would find safety. ${ }^{20}$

For other women, "survival" referred to the daily effort, over years and decades, to secure necessities for themselves and their families. The way this topic circulated through women's testimonies differed. First, it related to finding shelter and sufficient food. In many cases, necessities included discussions about their children's access to schooling and other opportunities. Stories of survival were also relayed in descriptions individual women gave of their work or the belongings they sold or sometimes stole. Furthermore, the topic of survival was evident in stories centred on making difficult decisions and sacrifices. Many spoke of extreme poverty and marginal living that involved daily struggles to provide food, shelter and other immediate needs for themselves, their children and other family members.

Many women had been income earners prior to the upheaval but, with the loss of a husband, the family's income dramatically reduced in most cases. In the first few months after a husband was arrested or killed, women often resorted to selling household goods and furniture and later perhaps even the family home. As one woman, "AR" - part of whose testimony is recorded in a report by the Indonesian National Commission on Violence against Women-recounted:

We had all been selling things for a long time, that was how I took care of my three children who had such bloated stomachs [from starvation] that kept on getting bigger. We sold the cupboard, the bed, [I] kept selling until ... we ended up sleeping on the floor. Luckily I had foster parents there [and] they often gave me rice. I didn't have anything there, not even any jewellery. I didn't think of myself at that time, I never thought I would be stuck in such a hole. Once I tried to sell things behind the school, but it was hard to sell anything because I was the wife of a PKI member. Only one or two people bought from me, I was broke again, [but I] kept going so I could feed the children. Everywhere I went I was ridiculed by people, that was how it was for me. ${ }^{21}$

20 This chapter draws on selected interviews with women survivors conducted by the author between 2002 and 2012, and on transcripts of interviews held by two Indonesian non-government organisations, the Lontar Foundation and the Indonesian Institute for Social History (Institut Sejarah Sosial Indonesia). Partial interview transcripts are also taken from the Komnas Perempuan (Indonesian National Commission on Violence Against Women) report (Gender-Based Crimes). The author conducted approximately 150 interviews with women survivors of the 1965-1966 mass killings as part of a large oral historiographical study into women's experiences during this period in various parts of Sumatra and Java, Indonesia. For a description of these interviews, see Annie Pohlman, Women, Sexual Violence and the Indonesian Killings of 1965-1966 (London: Routledge, 2015), 21n1.

21 Cited in Komnas Perempuan, Gender-Based Crimes, 128. 
This section of AR's testimony contains experiences that were common to many women after the death or detention of husbands. The loss of income, compounded by the social marginalisation and stigma faced by those associated with "Communist sympathisers," almost always meant direct and often severe economic hardship for family members. ${ }^{22}$ Whether the process happened over mere weeks or over years, families lost incomes, possessions, homes and land. In the testimonies of many women, this process is described as a relentless and distressing erosion of not only the family's sources of income and wealth but of their position within communities.

Research into the experiences of women who live through periods of conflict tends to focus on the gendered and gendering effects of that violence. Quite rightly, such research has revealed the broad range of gendered violence, particularly sexualised forms of violence, perpetrated frequently as part of conflict, crimes against humanity, war crimes and genocide. ${ }^{23}$ Where more research is needed is into women's lives in the aftermath of conflict; that is, into the years and decades of survival and rebuilding. As Tristan Borer argues, "[a]lthough it is clear that war is gendered, less recognised are the ways in which the post-war period is equally gendered." 24 As recent research into the lives of women in post- genocide situations has shown, more work is required to understand the social, economic and varying institutional constraints and opportunities faced by women in the immediate and long-term periods following mass violence. ${ }^{25}$

\section{Ibu Arum}

By her own account, Ibu Arum had a hard life, one in which she "worked every day to survive.”26 Born in the late 1930s in a poor area of southern

22 See Budiawan, "Living with the Spectre," 270-72; Wenhsien Huang, "Women and Political Detention in Indonesia,” Amnesty International, April 7, 1975, ASA 21/WH/CF.

23 For example, see Nira Yuval-Davis, Gender and Nation (London: Sage, 1997); Binaifer Nowrojee, Shattered Lives: Sexual Violence During the Rwandan Genocide and its Aftermath (New York: Human Rights Watch, 1996); Beverly Allen, Rape Warfare: The Hidden Genocide of Women in Bosnia-Herzegovina and Croatia (Minneapolis: University of Minnesota Press, 1996).

24 Tristan Anne Borer, "Gendered War and Gendered Peace: Truth Commissions and Postconflict Gender Violence: Lessons from South Africa,” Violence Against Women 15, no. 10 (2009), 1170.

25 Catherine Ruth Finnoff, “Gendered Vulnerabilities after Genocide: Three Essays on Post-Conflict Rwanda” (PhD thesis, University of Massachusetts, 2010); Jennie E. Burnet, Genocide Lives in Us: Women, Memory, and Silence in Rwanda (Madison: University of Wisconsin Press, 2012); Judy Ledgerwood, "Death, Shattered Families, and Living as Widows in Cambodia," in Plight and Fate of Women During and Following Genocide, ed. Samuel Totten (New Brunswick and London: Transaction, 2009), 67-82.

26 The transcript for the oral testimony by Ibu Arum (a pseudonym) is taken from the testimonial archives of the Indonesian Institute for Social History (ISSI), used with permission. 
Sumatra, she was orphaned during the Japanese occupation (1942-1945) by the time she was five. Raised by an uncle who worked in a rubber factory, she never attended school and married when she was 15 . She and her husband worked as day labourers on local plantations and cut and sold firewood from the nearby forest. Together they worked to accumulate a marginal income that paid for a small house and fed their three children.

As with many poor men in the area, in the mid-1950s her husband became involved in the Indonesian Communist Party's organisation for farmers and peasants, the BTI (Barisan Tani Indonesia), as well as another local labourers' union. ${ }^{27}$ During the 1950s and early 1960s, the BTI's membership grew substantially throughout many regions of Indonesia, particularly among landless peasants whose labour was critical to farming and forestry in Java and Sumatra. ${ }^{28}$ Attracted by the PKI's strong stance on land reform, as well as numerous programmes aimed at supporting the mostly landless agrarian labourers, the BTI, like other PKI-affiliated bodies, grew into an organisation with millions of members. ${ }^{29}$

In her testimony, Ibu Arum noted that in her area following the coup, a wave of killings and arrests occurred that lasted until early 1966. As in other parts of Sumatra, plantation workers in their region, many of whom had been members of the BTI and other unions, became targets during the massacres because of their affiliations with the PKI. ${ }^{30}$ Ibu Arum recalled that at night she could hear people being shot in the plantation near their home: "But people didn't talk about, they'd [refer to these events] only in code. Codes like, 'there's an operation going on in there,' things like that.” As she explained, she and all the other villagers who lived near the plantation knew what was happening and were frightened:

We were all terrified, when everything exploded and they were looking for people, they were rounding them up, and it went on for some time, the rounding up of people.... They were all the people accused of being in the PKI, or that they must have been in Gerwani (the PKI-affiliated women's

\footnotetext{
27 See Karl J. Pelzer, “The Agrarian Conflict in East Sumatra,” Pacific Affairs 30, no. 2 (1957), 151-59.

28 See Rex Mortimer, “Class, Social Cleavage and Indonesian Communism,” Indonesia 8 (1969), 1-20; Ernst Utrecht, "Land Reform in Indonesia,” Bulletin of Indonesian Economic Studies 5, no. 3 (1969), 71-88.

29 See Ernst Utrecht, "Land Reform and Bimas in Indonesia," Journal of Contemporary Asia, 3, no. 2 (1973), 149-64.

30 Joshua Oppenheimer and Michael Uwemedimo, "Show of Force: A Cinema-Séance of Power and Violence in Sumatra’s Plantation Belt,” Critical Quarterly 51, no. 1 (2009), 84-110; Hilmar Farid, “Indonesia’s Original Sin: Mass Killings and Capitalist Expansion, 1965-66,” Inter-Asia Cultural Studies 6, no. 1 (2005), 3-16; Ann Laura Stoler, Capitalism and Confrontation in Sumatra's Plantation Belt, 1870-1979 (New Haven: Yale University Press, 1985).
} 
organisation), that's what they said. Then they'd be taken, then taken away. And then they disappeared . . . in the forest.

In this initial wave of killings and arrests, Ibu Arum and her family were left alone. It was a few months later, when the military were carrying out a "clean-up" operation that her husband was arrested. These clean-up operations went on in some parts of Indonesia until approximately 1970. The Indonesian Army worked with local governments and other civilians to identify and detain remaining PKI supporters (often called "PKI malam” or "night PKI"), particularly in rural areas. ${ }^{31}$ Aimed at rounding up PKI supporters who had escaped initial purges, these clean-up operations also targeted those seen to be closely aligned with the "Old Order"-the retrospective name given to President Sukarno's government by the Suharto regime to distinguish it from the "New Order" post-1966. ${ }^{32}$ Throughout the late 1960s, government departments, various branches of the military and a wide range of formal labour sectors were also cleansed of suspected "PKI elements"; those removed were then sent to one of the many detention camps established for the purpose of holding hundreds of thousands of political prisoners. ${ }^{33}$

Ibu Arum recalled how soldiers led the clean-up operation amongst the plantation workers and how local members of their community also participated: "One of our neighbours, he was the one who got involved in this, that's what he did.” As Ibu Arum explained, “The [soldiers] would come out at night and take people. And he was the one who wrote down each of their names. ... Our neighbour, he wrote down names on a list of people from around here, all of them. . . . I'm not sure why he did it, but they [the soldiers] told him to do it, and they paid him to do it too, that's what happened.” Ibu Arum's husband was one of those whose name was added to the list of unionists and other alleged PKI supporters given by their neighbour to the soldiers.

One evening, they came for him. His name was on the list. He was out in the plantation still, getting firewood to sell along with my uncle, and they took him from there, in the forest. . . . It was only about one kilometre from our home. They [a group of soldiers] followed him into the middle of the

31 See Justus van der Kroef, "Indonesian Communism Since the 1965 Coup,” Pacific Affairs 43, no. 1 (1970), 34-60.

32 See HD. Haryo Sasongko and Melanie Budianta, eds., Menembus Tirai Asap: Kesaksian Tahanan Politik 1965 (Jakarta: Lontar Foundation, 2003).

33 See van der Kroef, "Indonesia’s Political Prisoners,” 34-38; van der Kroef, "Indonesian Communism,” 34-40. 
plantation and arrested him there. Then they took him to the local military command post [Kodim].

Ibu Arum's uncle was not arrested, and came back to tell her that armed soldiers had taken her husband. Ibu Arum was terrified about what might happen to her husband at the command post. "We knew what was happening there. People said that at the command post, people were being beaten and tortured. They said they were tying people up, beating them. . . I was scared to go to the command post, but I was also scared for [my husband].” The command post was located in the nearby town and she and a few other women whose husbands had been kidnapped made the three-hour journey on foot.

When they arrived, the soldiers harassed them and ate the food they had brought for their husbands. Ibu Arum recalled how she and another woman were slapped across the face for asking to see their husbands, and both told to wait in a side-room of the command post. "So we went into the room, and there were people getting electric shocks [in the next room], crying, we could hear them doing it. . . . I could hear them being beaten, thrashed.” After waiting for a few hours, the women were told to go home without seeing their husbands.

Thus began a new and more "terrible way of living," as Ibu Arum described it, for herself and for the other women from the plantation whose husbands had been arrested. "Once a week, we would walk there [to the command post], we would leave at $5 \mathrm{a} . \mathrm{m}$. and get there by 8 a.m., we would take food in for the men, because they had none. . . . There would be four, maybe five of us at a time, whoever could go, but someone would stay at home with the children.” As in many of the detention camps across Indonesia during the late 1960s, the political detainees held at the command post were starving. ${ }^{34}$ Ibu Arum's husband, along with others, received almost no food rations from their jailors and relied on what little food family members were able to bring. However, the food that she and the other women brought was almost always taken by the soldiers and only some of it passed on to detainees.

As Ibu Arum explained, sustenance for the women themselves and their children was also a constant struggle. Over the three years Ibu Arum's husband and the other men from the planation were detained, Ibu Arum and her small circle of friends cooperated to keep themselves, their husbands and their children fed as best they could. Without this cooperation, Ibu Arum insisted, none of them would have survived:

34 See Carmel Budiardjo, "Political Imprisonment in Indonesia," Bulletin of Concerned Asian Scholars 6, no. 2 (1974), 20-23. 
We all had children, most of them small children, all of us wives. The children were little, some of them just babies. I myself had three little ones ... one was eight, the second one was five, and the third one was just two.... All of our men had been put inside, and we all really struggled. So we went to work and we worked together. I went to work back in the plantation. The rubber plantation was nearby, just behind where our houses were. I got out and worked hard. I also went to the forest to collect firewood, to sell. My friends did this too.... One of us would stay with the children, the [others] would go work, so that we would have food.

This small group of women took turns working at the plantation or scavenging for firewood to sell at the market. One woman would always stay with the children and, as some of the older children grew up, they too went to work hunting for firewood or looked after the younger ones. The children would also make the weekly journey to the command post to deliver what little food they could spare for the imprisoned men. Cooperation between the women "kept us all alive, thanks be to God. Without [it], we would be dead. Starved."

After three years, Ibu Arum's husband and the other men were gradually released. Each of the men was forced to "report back" to the command post once a week (wajib lapor); each time they had to pay the soldiers 1000 Rupiah (roughly the cost of feeding an extended family for at least a few weeks) to stay out of detention and they were often forced to perform free labour. The mandatory bribes and additional forced labour meant that Ibu Arum's family, as with other families from the plantation, struggled for subsistence. Yet, as Ibu Arum explained, "we were blessed . . . we were together." As she also made clear, they had been "blessed" because none of their husbands had been murdered or starved to death while in detention: "they all came home, and not many did.”

\section{Ibu Moeliek}

Ibu Moeliek was born in the early 1930s in West Sumatra. ${ }^{35}$ Though interrupted by the Second World War and the Japanese occupation (1942-1945), followed by the struggle for independence from the Dutch (1945-1949), Ibu Moeliek received a primary education and was married in her mid-twenties to a high-ranking local member of government. Her husband, Pak "A," was a supporter of the PKI and became a leader within the BTI, and Ibu Moeliek

35 Interview, recorded with permission, with Ibu Moeliek and Ibu Jusufa, together with Narny Yenny, September 2005, West Sumatra. 
herself became quite heavily involved in running one of the Taman Melati (Melati Gardens) kindergartens in their city. These crèches were set up by Gerwani-the popular women's organisation closely aligned with the PKI-to help women in communities across Indonesia. ${ }^{36}$ Aside from her work with the Taman Melati, Ibu Moeliek became increasingly involved with organising other activities through the city's Gerwani branch.

Shortly after the coup, anti-PKI violence broke out in the city and surrounding villages. Ibu Moeliek's husband, Pak A, as a public official with close links to the PKI, knew that he would become a target. After an angry mob came looking for him at his office in town, Pak A told his wife that he had to flee, saying that she and their four young children would be alright. "But we weren't. And [he] left, ran into the forest.” In that part of Sumatra, the city lies on the coast and the hills behind are covered with dense rainforest. During the anti-Communist purges that started in the region mid-October 1965 and continued for some months, many members of the PKI and affiliated organisations went on the run, attempting to hide in the forest. Another woman from this area explained that soldiers and groups of civilian militias would go "pig hunting." She described how, when the mob caught someone, "they'd slaughter them near the mountain top. They'd be pulled along by their feet . . . suspended by their feet, by their hands . . . like they were carrying a pig. After they cut [the victim's throat], blood would spill out everywhere. They'd all come down together, [calling], 'We've got one! We've got a pig!' ’37

After Pak A had fled to the forest, Ibu Moeliek explained how people came looking for him. "I was still at home with the children. [Shortly after] Pak A left, for three nights the police came looking for him. They came at one in the morning, 2 a.m., sometimes 3 a.m.. Yelling, harassing us.” This went on for some time while Pak A was on the run and she recalled how the harassment by policemen, soldiers and mob members frightened her and her young children. "We were all terrified [every] time they came. Our youngest wasn't even four years old yet, the next one was in kindergarten, the third one was in Year Two at school and the oldest one well, he was suffering. I had to find food for all five of us."

After five months of hiding in the forest, Ibu Moeliek's husband was captured by a mob of civilian militias and soldiers. Dragged out of the forest along with other PKI members who had been hiding, Pak A was taken to the city's main police station. Ibu Moeliek found out from friends that he had been captured and went to the police station to see him when she could: 
I had the chance to go see him there. I went to see him with the children. ... He was detained there for five months, but after one time [after I had gone to see him], two days later I found out that he'd been shot. They said it happened when they [the detainees] were taken out and taken across the road near the [town] market. He was shot there near the police station, in front of that market. Another man was shot too, with [my husband]. They were shot from behind by a policeman, in the back of the head ...

For the five months Pak A was detained at the police station, Ibu Moeliek took their children to see him whenever able, bringing food with her. As similarly described by Ibu Arum, detainees held at the city's police station were starving. Ibu Moeliek was never able to find out the exact details of her husband's death but believed her husband and the other victim had been taken from the police station and executed. She believed the public nature of his execution was due to his "position within the PKI" and that he was made an example of because of the public office he had held within the government.

In Ibu Moeliek's testimony, she emphasised that from the time her husband fled into the forest, she and her children suffered a great deal. She explained that without her husband's income they were starving. "There was nothing I could do. At first, I just kept crying with my children because how would I be able to feed them? We had nothing anymore ... and then, after what happened at the police station, when my husband was no more, then we really suffered.” During those first few months, Ibu Moeliek gradually sold household items to pay for food and then she sold "whatever else I could find." Eventually, she had sold everything in their house:

By then, we had nothing to eat. My children had no father to get food for them. So I worked. So then I went out and cleaned, I cleaned peoples' clothes . . . I would work for whoever would let me, I would clean their clothes and get a little bit of money. Then my oldest girl, she was still little, but then she started helping me to clean clothes too.

Ibu Moeliek explained that, for a time, they managed to survive on the money brought in by herself and her oldest daughter (the second child). She received no help from family or friends who had all "turned away" from her, but she added that, "Not everyone was bad to us. Some people felt sorry for us. They saw a mother with four hungry children and felt sorry for us . . . but many people, they cursed us, rejected us.... [They] cursed the children and called them 'PKI children' and things like that." The term "anak PKI" or "PKI child” be- 
came a common epithet used against the children of those who were murdered or detained following the 1965 coup. $^{38}$

Her own parents were very old and were only able to help on occasion. The only time Ibu Moeliek was able to get help from her husband's family was just before her oldest child died. As she explained during our interview:

I went many times [in the beginning]. I went back and asked them again for rice for my child when he was dying. I came home that day with half a small bag of rice and they told me never to come again. They would not give us anymore, not again. That's what my parents-in-law said to me. . . . [T]hey were rich. But they wouldn’t help us.

Ibu Moeliek explained that her parents-in-law were angry with their son for his involvement in the PKI and blamed him for being killed. They cut all ties with their son's children.

Ibu Moeliek described a sequence of events she called "the most devastating” of her life. Shortly after going to see her parents-in-law to beg for food, her oldest child, a son, died. He had been sick for a while and Ibu Moeliek blamed the lack of food that would have "kept him strong." Shortly after, she was arrested and taken to the police station:

I was kept inside for a month. The three [remaining] children were left all by themselves, to find food for themselves, even the little one. The oldest one [her second child, a daughter] sold off the rest of our possessions, everything. That's how they were able to get food. They came to see me when I was in detention, and they were starving. . . . It broke my heart. My children were starving, I wasn't there to get them food. I was devastated, and terrified about what would happen to them.

Ibu Moeliek did not speak much about her treatment during detention at the police station; as she explained, her focus was on getting out as fast as she could to take care of her children. At the end of the month she was released along with some other women; only a small number of women had been detained at the police station, whereas "hundreds of men were being kept there," all of them "packed tightly into rooms, like animals, starving." As with most former political prisoners, Ibu Moeliek was required to make "reports" to local authorities for many years.

38 See Andrew Conroe, "Generating History: Violence and the Risks of Remembering for Families of Former Political Prisoners in Post-New Order Indonesia” (PhD thesis, University of Michigan, 2012). 
After her release from detention, Ibu Moeliek needed to find a "better-paid job"; cleaning clothes did not bring in enough money. She found work as a housemaid for a family in another part of the city and the income was sufficient to feed her children. A year or so later she found another job as a housemaid for a different family who let her and her children live in the back section of their house. She stayed for nearly 10 years and had enough money to feed her children and, eventually, to send them to school. Once she and her children had moved in with this second family, Ibu Moeliek reflected, their "lives got better, not everything was hard all the time. I was happy. We had food, the children were able to go to school, and they [the family she worked for] were good to us." After 10 years, and with her children mostly grown up, she married a man who had also been a political prisoner. After his death in the early 2000s, Ibu Moeliek went to live with one of her daughters and her grandchildren.

\section{Finding a way}

Ibu Arum's and Ibu Moeliek's experiences during and after the mass killings and arrests of 1965-1966 share many similarities. Like so many women, they faced a range of increasingly demanding and dangerous circumstances and choices, including attacks by soldiers, police or civilian militias. The numerous deprivations imposed by the loss of income and connections had to be negotiated and new social relations managed. As their testimonies highlight, the immediate priorities of finding food and safety became the main focus.

In her testimony, Ibu Arum focused on the difficulties that she and her young children endured during the three years of her husband's detention. For her, the only way she was able to survive this period was due to the mutual help and cooperation between herself and a small group of like-situated wives. As she outlined, by working together to secure income for food, as well as sharing the childcare, they survived. Ibu Moeliek, by comparison, was cut off by relatives and from other support mechanisms. She and her family were on the verge of starvation and her oldest child, already ill, perished from lack of food. Ibu Arum's husband survived detention, whereas Ibu Moeliek's husband was taken from detention and publicly executed. Both endured and both survived, but like so many other women affected by the mass violence of 1965 , they lost loved ones as well.

Both testimonies give witness to women's daily acts of survival in the face of violence, severe economic stress and social marginalisation. Their stories reveal some of the ways in which women negotiated these circumstances and 
the choices they made in order to survive. Moreover, the testimonies of Ibu Arum and Ibu Moeliek reveal the social, economic and other constraints faced by women in the immediate and long-term periods after mass violence, which are so often neglected in the histories of this period. 